Check for updates

Cite this: RSC Adv., 2018, 8, 38436

Received 18th September 2018 Accepted 29th October 2018

DOI: $10.1039 / c 8 r a 07745 b$

rsc.li/rsc-advances

\section{A sensitive electrochemical assay for T4 polynucleotide kinase activity based on titanium dioxide nanotubes and a rolling circle amplification strategy $\dagger$}

\author{
Yanli Zhang, ${ }^{a}$ Xiang Fang, ${ }^{a}$ Zhenyu Zhu, ${ }^{a}$ Yanqiong Lai, ${ }^{a}$ Chunli Xu, ${ }^{a}$ Pengfei Pang, (DD *a \\ Hongbin Wang, ${ }^{a}$ Chun Yang, ${ }^{b}$ Colin J. Barrow (D) ${ }^{c}$ and Wenrong Yang (D) ${ }^{c}$
}

\begin{abstract}
An ultrasensitive electrochemical biosensor was developed for detection of T4 polynucleotide kinase (T4 PNK) activity based on titanium dioxide nanotubes $\left(\mathrm{TiO}_{2} \mathrm{NTs}\right)$ and a rolling circle amplification (RCA) strategy. In this study, the immobilized T4 PNK substrate probe with a $5^{\prime}$ terminus hydroxyl was phosphorylated by T4 PNK in the presence of adenosine triphosphate (ATP), and the resulting 5phosphoryl can be linked with the $\mathrm{TiO}_{2} \mathrm{NTs}$ and further conjugated with the phosphate-labeled primer. RCA was initiated by adding circular template, phi29 DNA polymerase and deoxyribonucleoside 5triphosphate mixture (dNTPS). Biotin-labeled probes are chosen as a signal indicator by strong biotinstreptavidin interaction and the high loading of horseradish peroxidase-streptavidin (HRP-SA) for electrochemical signal generation and amplification. A dual-signaling amplification strategy has been established, which exhibited an excellent performance with a wide linear range from 0.0001-15 $U \mathrm{~mL}^{-1}$ and a low detection limit of $0.00003 \mathrm{U} \mathrm{mL}^{-1}$ for T4 PNK detection. The inhibition effect of $\left(\mathrm{NH}_{4}\right)_{2} \mathrm{SO}_{4}$ on the activity of T4 PNK is also evaluated. This new dual-signaling electrochemical biosensor can be used for the detection of the activity and inhibition of other nucleic acid enzymes.
\end{abstract}

\section{Introduction}

T4 polynucleotide kinase (T4 PNK) is a well-known member of the 5'-kinase family, since it was discovered in 1965 in protein extracts of Escherichia coli bacteria infected with T-even bacteriophage. ${ }^{1}$ It has become one of the most frequently used enzymes in molecular biology. It is able to catalyze the transfer of the $\gamma$-phosphate residue from adenosine triphosphate (ATP) to the $5^{\prime}$-terminus of polynucleotides or to mononucleotides bearing a $5^{\prime}$-hydroxyl group. ${ }^{2,3}$ Furthermore, T4 PNK is very important for cellular nucleic acid metabolism, particularly in the cellular responses to DNA damage, which relates to many human disorders such as Werner syndrome, Bloom's syndrome, and Rothmund-Thomson syndrome. ${ }^{4}$ Additionally, T4 PNK is also widely used in the detection of DNA adducts or oligonucleotides and in the repair of nucleic acid lesions. ${ }^{5-7}$ Therefore, accurate monitoring of PNK activity and its potential

${ }^{a}$ Key Laboratory of Comprehensive Utilization of Mineral Resources in Ethnic Regions, Yunnan Minzu University, Kunming 650500, P. R. China.E-mail: pengfeipang@yahoo. com; Fax: +86 871 65910017; Tel: +8687165910017

${ }^{b}$ Shaanxi Geological Survey Center, Xi'an 710068, P. R. China

${ }^{c}$ School of Life and Environmental Sciences, Deakin University, Geelong, VIC 3217, Australia

$\dagger$ Electronic supplementary information (ESI) available. See DOI: $10.1039 / \mathrm{c} 8 \mathrm{ra} 07745 \mathrm{~b}$ inhibitors are of considerable importance in nucleic acid metabolism research and molecularly targeted therapy.

Until now, various approaches for the determination of DNA phosphorylation have been developed. Conventionally, the activity of T4 PNK was detected via these sophisticated protocols, such as radioisotope ${ }^{32} \mathrm{P}$-labeling, autoradiography, and polyacrylamide gel electrophoresis (PAGE). ${ }^{5,8-13}$ These methods are well established, but some of them suffer from potential radioactive contamination and/or labor-intensive procedures. To overcome these limitations, more sensitive and convenient T4 PNK assays including fluorescent, ${ }^{14-18}$ colorimetric, ${ }^{19-21}$ bioluminescent ${ }^{22}$ and photoelectrochemical ${ }^{23,24}$ methods have been developed. Compared to the methods mentioned above, electrochemical biosensors have attracted much attention in T4 PNK assay due to high sensitivity, low-cost, low power requirement and high compatibility. ${ }^{25-31}$ Though the progress of these electrochemical approaches have been successfully made for the detection of T4 PNK activity and screening its inhibitors, it still remains a challenge to develop simple, rapid, accurate and sensitive electrochemical methods for T4 PNK activity assay.

The phosphate group at the $5^{\prime}$-terminal of DNA is important for achieving the sensitive detection of PNK activity. $\mathrm{Ti}^{4+}, \mathrm{TiO}_{2}$ and $\lambda$ exonuclease were widely used as identification reagents. ${ }^{17,25,27,32-34}$ For instances, Wang et al. developed an electrochemical strategy for monitoring the activity and 
inhibition of T4 PNK based on $\mathrm{Ti}^{4+}$ mediated signal transition coupled with signal amplification of single wall carbon nanotubes ${ }^{32}$ which a signal amplified method for the electrochemical determination of T4 PNK activity based on the peroxidase-like activity of magnetite microspheres, the specific recognition capabilities of $\mathrm{TiO}_{2}$ with the phosphate groups of the capture probe and the DNA dendrimer structure for signal amplification. ${ }^{34}$ Furthermore, Cui et al. and Hou et al., respectively, successfully screened DNA phosphorylation process based on AuNP-mediated $\lambda$ exonuclease cleavage and $\lambda$ exonuclease enzyme reaction and bimolecular beacons-induced signal amplification. ${ }^{17,27}$ On the basis of these research progress, metal oxides $\mathrm{TiO}_{2}$ have been shown as an effective capture material for selective enrichment of phosphorylated peptides, and thus the phosphate functional groups can bonded to the surface of $\mathrm{TiO}_{2}$ nanotubes. ${ }^{33}$ Through the appropriate signal amplification strategy, the improvement of sensitivity and analytical performance for T4 PNK activity detection should be reasonably conceivable.

Inspired by the electrochemical approaches of coupling rolling circle amplification (RCA) strategy, ${ }^{35-38}$ we designed a novel and sensitive electrochemical biosensor for the detection of T4 PNK activity with dual-signaling amplification. RCA is an isothermal nucleic acid amplification technique, which has been widely used as an important technique for ultrasensitive DNA, RNA, and protein detection in diagnostic genomics and proteomics. ${ }^{39-46}$ RCA is an attractive tool for biosensor fabrication, especially for the development of electrochemical biosensors. Owing to the accumulation of RCA products on electrode surface, the electrochemical signal can be greatly amplified after an elaborated design so as to improve the detection sensitivity. With $\mathrm{TiO}_{2}$ nanotubes as a PNK catalytic phosphorylation identifier and RCA as the signal amplifier, facile and ultrasensitive monitoring of the T4 PNK activity can be developed. To the best of our knowledge, this is the first study of coupling dual-signaling amplification and RCA technique for sensitive detection of T4 PNK activity and inhibition.

\section{Experimental section}

\subsection{Reagent and apparatus}

$\mathrm{TiO}_{2}$ powder was supplied by Shanghai Titan Scientific Co., Ltd. (Shanghai, China). The 6-mercapto-1-hexanol (MCH) was purchased from J\&K Scientific Co., Ltd. (Beijing, China). T4 polynucleotide kinase (T4 PNK) and adenosine triphosphate (ATP) were obtained from Sangon Biotech Co., Ltd. (Shanghai, China). Phi29 DNA polymerase, BSA and Phi29 buffer were purchased from New England Biolabs (Beijing, China). Deoxyribonucleoside 5-triphosphate mixture (dNTPs), T4 DNA ligase and Klenow fragment DNA polymerase (KF) were supplied by Takara Bio Inc (Japan). HRP-conjugated streptavidin (HRP-SA) was obtained from BBI Life Sciences (Shanghai, China), and hydroquinone (HQ) were purchased from Sinopharm Chemical Reagent Co., Ltd. (Shanghai, China). All other reagents were of analytical grade and used as received without further purification.

All the oligonucleotides were synthesized and purified by Sangon Biotechnology Co., Ltd. (Shanghai, China). The oligonucleotide sequences are listed in Table 1. Washing buffer was $10 \mathrm{mM}$ Tris- $\mathrm{HCl}$ containing $0.4 \mathrm{M} \mathrm{NaCl}$. Ligation buffer was $66 \mathrm{mM}$ Tris- $\mathrm{HCl}$ (pH 7.6) containing $6.6 \mathrm{mM} \mathrm{MgCl}_{2}, 10 \mathrm{mM}$ DTT, and 0.1 mM ATP. Ultrapure water obtained from a Millipore filtration system was used throughout all experiments.

Cyclic voltammetry (CV), differential pulse voltammetry (DPV) and electrochemical impedance spectroscopy (EIS) measurements were carried out on a CHI660D electrochemical workstation (CHI Instrument Company, Shanghai, China). Scanning electron microscopy (SEM) images were measured by NOVA NANOSEM 450 model with ultra-high resolution field emission scanning electron microscopy (FEI, USA). Transmission electron micrograph (TEM) images were obtained using a JEM-2100 microscope (Jeol, Japan). The gel electrophoresis was performed on the DYCP-31BN Electrophoresis Analyser (Liuyi Instrument Company, China) and imaged on the Bio-rad ChemiDoc XRS (Bio-Rad, USA). A standard three-electrode system was employed with gold electrode as working electrode, a platinum (Pt) sheet as an auxiliary electrode, and a saturated calomel electrode (SCE) as a reference electrode, respectively.

\subsection{Synthesis of $\mathrm{TiO}_{2}$ NTs}

$\mathrm{TiO}_{2}$ NTs were synthesized by a hydrothermal method. Briefly, $0.2 \mathrm{~g}$ of titanium dioxide powder was added into $20 \mathrm{~mL}$ of $10 \mathrm{M}$ $\mathrm{NaOH}$ solution and stirred vigorously for $30 \mathrm{~min}$. The mixed solution was sealed in a teflon-lined stainless-steel autoclave and heated at $120{ }^{\circ} \mathrm{C}$ for $24 \mathrm{~h}$, and then cooled to room temperature. The obtained product was washed several times with $0.1 \mathrm{M} \mathrm{HCl}$ and water until the $\mathrm{pH}$ was neutral. After centrifugation, $\mathrm{TiO}_{2} \mathrm{NTs}$ were dried in an oven at $80{ }^{\circ} \mathrm{C}$ and ground to a powder before use.

\subsection{Self-assembly of substrate DNA and phosphorylation}

Prior to modification, the gold electrode ( $2 \mathrm{~mm}$ in diameter) was firstly polished to a mirror-like surface with 0.3 and 0.05 $\mu \mathrm{m}$ alumina powder, respectively, followed by successive

Table 1 Sequences of the oligonucleotides used in this work

\begin{tabular}{ll}
\hline Name & Sequence $\left(5^{\prime}-3^{\prime}\right)$ \\
\hline S1 & $5^{\prime}$-OH-GTG CTG GTC GTG CTG TAG TAG-SH-3' \\
S2 & $5^{\prime}-\mathrm{PO}_{4}$-AGT GAC TCG GGC GAA GAC AGG TGC TTA GT-3' \\
S3 & $5^{\prime}-\mathrm{PO}_{4}$-TGT CTT CGC CTT CTT GTT TCC TTT CCT TGA AAC TTC TTC \\
S4 & CTT TCT TTC TTT CGA CTA AGC ACC-3' $^{\prime}$
\end{tabular}


sonication with ultrapure water, ethanol and ultrapure water for $5 \mathrm{~min}$ each. The electrode was then immersed into fresh piranha solution $\left(\mathrm{H}_{2} \mathrm{SO}_{4}: \mathrm{H}_{2} \mathrm{O}_{2}=3: 1, \mathrm{v} / \mathrm{v}\right)$ for $1 \mathrm{~h}$, followed by a thorough rinse with ultrapure water. Subsequently, the gold electrode was electrochemically cleaned in $0.5 \mathrm{M} \mathrm{H}_{2} \mathrm{SO}_{4}$ solution by potential scanning between -0.2 and $+1.6 \mathrm{~V}$ at a scan rate of $50 \mathrm{mV} \mathrm{s}^{-1}$ until a stable reproducible cyclic voltammogram was obtained. After washing with ultrapure water and drying by nitrogen, the electrode was incubated with $5 \mu \mathrm{L}$ of 1 $\mu \mathrm{M}$ hydroxyl-labeled substrate DNA (S1) at $30{ }^{\circ} \mathrm{C}$ for $12 \mathrm{~h}$ to make $\mathrm{S} 1$ immobilize onto the gold electrode surface via $\mathrm{Au}-\mathrm{S}$ bond. The obtained S1/Au was rinsed with washing buffer and incubated with $5 \mu \mathrm{L}$ of $1 \mathrm{mM} \mathrm{MCH}$ at room temperature for 20 min to eliminate the nonspecific-bonded DNA. For phosphorylation of S1, $5 \mu \mathrm{L}$ of T4 PNK reaction buffer containing 3 mM ATP and different concentrations of T4 PNK was dropped on the electrode surface, and the electrode was incubated at $37^{\circ} \mathrm{C}$ for $2 \mathrm{~h}$ in a humidified chamber. After being rinsed with washing buffer, modification of the $\mathrm{TiO}_{2}$ NTs on the phosphorylated S1 (P-S1) was carried out by incubating P-S1 with $5 \mu \mathrm{L}$ of $0.6 \mathrm{mM} \mathrm{TiO}_{2}$ NTs solution for $2 \mathrm{~h}$ at room temperature to capture $\mathrm{TiO}_{2}$ NTs on P-S1 based on the specific adsorption of the phosphorylation sites and $\mathrm{Ti}^{4+}$, and linkage between $\mathrm{TiO}_{2}$ NTs and P-S1 $\left(\mathrm{TiO}_{2} / \mathrm{P}-\mathrm{S} 1 / \mathrm{Au}\right)$ was processed. ${ }^{25,34,39}$ With different concentrations of T4 PNK for phosphorylation, the related amounts of $\mathrm{TiO}_{2} / \mathrm{P}-\mathrm{S} 1$ were obtained. The $\mathrm{TiO}_{2} / \mathrm{P}-\mathrm{S} 1 / \mathrm{Au}$ was washed with washing buffer and stored at $4{ }^{\circ} \mathrm{C}$ prior to use.

\subsection{Preparation of circularization mixture and RCA reaction}

For preparation of circularization mixture, $10 \mu \mathrm{L}$ of $1 \mu \mathrm{M}$ primer chain $\mathrm{S} 2$ and $10 \mu \mathrm{L}$ of $1 \mu \mathrm{M}$ circular template $\mathrm{S} 3$ were mixed to $98 \mu \mathrm{L}$ of the ligation buffer and incubated at $37^{\circ} \mathrm{C}$ for $30 \mathrm{~min}$, followed by the addition of $2 \mu \mathrm{L}$ of $5 \mathrm{U} \mathrm{mL}^{-1} \mathrm{~T} 4$ DNA ligase and incubation at $37{ }^{\circ} \mathrm{C}$ for $1 \mathrm{~h}$. After ligation, T4 DNA ligase was inactivated by heating the reaction mixture at $65{ }^{\circ} \mathrm{C}$ for $10 \mathrm{~min}$. The obtained circularization mixture was stored at $-20{ }^{\circ} \mathrm{C}$ for further use. Afterwards, $5 \mu \mathrm{L}$ of $0.06 \mu \mathrm{M}$ circularization mixture was dropped onto the $\mathrm{TiO}_{2} / \mathrm{P}-\mathrm{S} 1 / \mathrm{Au}$ electrode surface and incubated at room temperature for $2 \mathrm{~h}$. Following rinsing with washing buffer, RCA reaction was initiated by addition of $5 \mu \mathrm{L}$ reaction buffer $\left(1 \mathrm{mM}\right.$ dNTPs, $20 \mathrm{U} \mathrm{mL}^{-1}$ phi29 DNA polymerase, and $1 \mathrm{mM}$ BSA) and continued for $1 \mathrm{~h}$ at $37^{\circ} \mathrm{C}$.

After washing with washing buffer, $5 \mu \mathrm{L}$ of $10 \mu \mathrm{M}$ biotinlabeled detection probe $\mathrm{S} 4$ was dropped onto electrode surface and hybridized at $37{ }^{\circ} \mathrm{C}$ for $30 \mathrm{~min}$. Following rinsing with washing buffer, $5 \mu \mathrm{L}$ of $10 \mu \mathrm{g} \mathrm{mL}{ }^{-1}$ streptavidin-horseradish peroxidase (HRP-SA) was added on biosensor surface and incubated at $37{ }^{\circ} \mathrm{C}$ for $30 \mathrm{~min}$.

\subsection{Native gel electrophoresis}

RCA reaction mixtures were incubated for $4 \mathrm{~h}$ at $37{ }^{\circ} \mathrm{C}$. A $3 \%$ agarose gel electrophoresis analysis was carried out in $0.5 \times \mathrm{TBE}$ buffer (90 mM Tris, $89 \mathrm{mM}$ boric acid, $2.0 \mathrm{mM}$ EDTA, and $\mathrm{pH}$ 8.0) at a constant potential of $120 \mathrm{~V}$ for $40 \mathrm{~min}$. After being stained with bromophenol blue, the image of gel electrophoresis was obtained using a Gel Doc XR+ system (Bio-Rad).
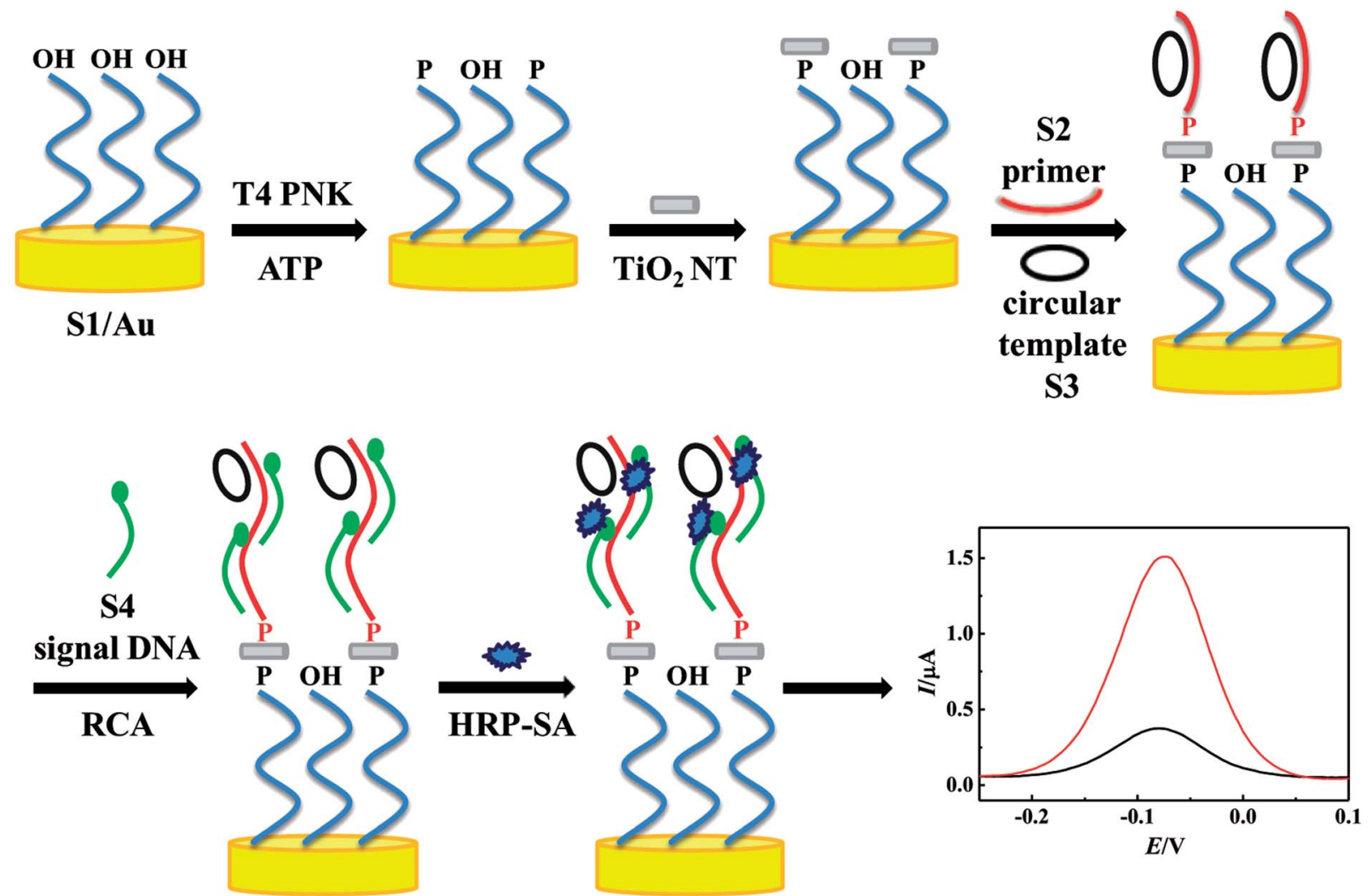

Scheme 1 Schematic illustration of the electrochemical assay for T4 PNK activity based on $\mathrm{TiO}_{2} \mathrm{NTs}$ and RCA strategy. 

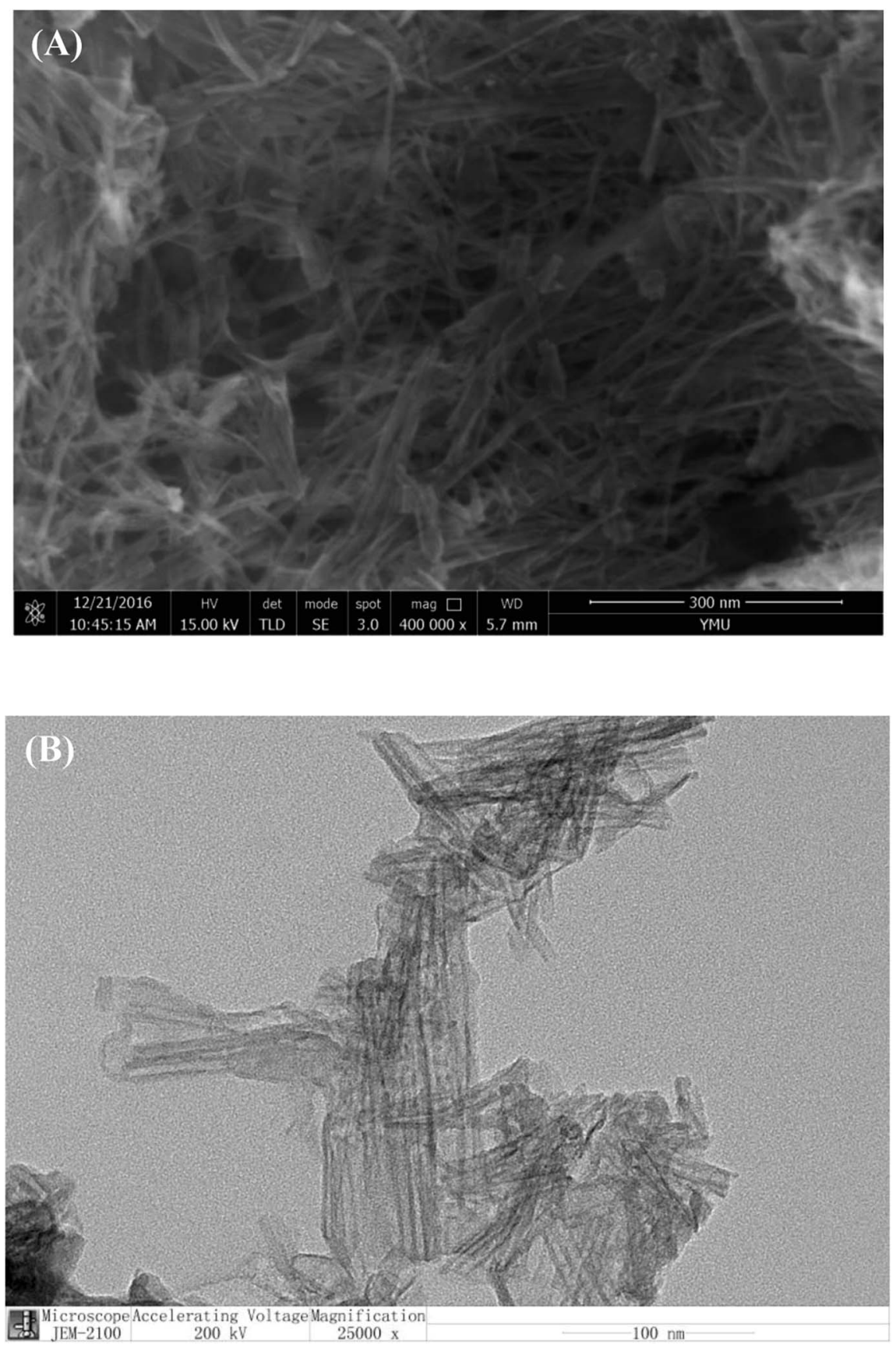

Fig. 1 (A) SEM and (B) TEM images of prepared $\mathrm{TiO}_{2}$ nanotubes.

\subsection{Electrochemical measurement}

The modified electrode was carefully washed with washing buffer to perform CV, DPV and EIS. CV was carried out in $10 \mathrm{mM}$ Tris- $\mathrm{HCl}$ ( $\mathrm{pH}$ 7.4, containing $0.1 \mathrm{M} \mathrm{NaCl}, 1 \mathrm{mM} \mathrm{H}_{2} \mathrm{O}_{2}$ and $1 \mathrm{mM}$ $\mathrm{HQ}$ ) within the potential range from -0.4 to $0.4 \mathrm{~V}$ at a scan rate of $0.1 \mathrm{~V} \mathrm{~s}^{-1}$. DPV was performed in $10 \mathrm{mM}$ Tris- $\mathrm{HCl}(\mathrm{pH} \mathrm{7.4)} \mathrm{in}$ the potential range from -0.3 to $0.1 \mathrm{~V}$ with a pulse amplitude of $50 \mathrm{mV}$ and a width of $20 \mathrm{~ms}$. EIS was recorded in $20 \mathrm{mM}$ PBS (pH 7.4) containing $5 \mathrm{mM} \mathrm{Fe}(\mathrm{CN})_{6}{ }^{3-/ 4-}, 0.1 \mathrm{M} \mathrm{KCl}$ and $0.1 \mathrm{M}$ $\mathrm{NaClO}_{4}$ within the frequency range of $0.1 \mathrm{~Hz}$ to $100 \mathrm{kHz}$ at amplitude of $0.05 \mathrm{~V}$ and applied potential of $0.2 \mathrm{~V}$. All electrochemical experiments were carried out at room temperature.

\section{Results and discussion}

\subsection{Strategy for T4 PNK activity detection}

The schematic diagram of the proposed electrochemical biosensor for PNK activity detection is shown in Scheme 1. The thiolated substrate DNA S1 with 5'-hydroxyl group was first selfassembled on the gold electrode through $\mathrm{Au}$-thiol interaction. This substrate S1 modified gold electrode (S1/Au) was then backfilled with $\mathrm{MCH}$ to prevent the nonspecific adsorption. Subsequently, the phosphorylation site at the $5^{\prime}$-termini of the substrate $\mathrm{S} 1$ was introduced in the presence of T4 PNK and ATP, obtaining the phosphorylated S1 (P-S1/Au). Afterwards, $\mathrm{TiO}_{2}$ 
NTs were added and linked with the P-S1 through the steady interaction between $\mathrm{Ti}^{4+}$ and phosphate groups, leading to $\mathrm{TiO}_{2} / \mathrm{P}-\mathrm{S} 1 / \mathrm{Au}$ for anchoring the RCA primer (S2) and circular template (S3). After adding the circularization mixture, RCA was initiated in the presence of phi29 DNA polymerase and dNTPs to produce massive long single-strand DNA molecules with multiple tandem-repeat sequences. Then, a large number of biotin-labeled probes $\mathrm{S} 4$ were assembled on the RCA products for capturing the HRP-SA through strong biotin-streptavidin interaction. Finally, electrocatalytic activity of HRP-tagged RCA product for $\mathrm{H}_{2} \mathrm{O}_{2}$ reduction by oxidation of hydroquinone (used as an electron transfer mediator) can be significantly improved, resulting in an enhanced electrochemical response. The produced electrochemical signal was related to the amount of HRP-tagged RCA bioconjugate on the electrode surface, which depended on the activity of T4 PNK.

\subsection{Characterization of $\mathrm{TiO}_{2}$ nanotubes}

The obtained $\mathrm{TiO}_{2}$ nanotubes were characterized by SEM and TEM. Fig. 1 shows $\mathrm{TiO}_{2}$ NTs have a uniform size, high density and well-ordered morphology. We observed $\mathrm{TiO}_{2}$ NTs were packed in regular structure consisting of hollow tubes. The average length of $\mathrm{TiO}_{2}$ NTs was about $100 \mathrm{~nm}$ with a diameter of $10 \mathrm{~nm}$.

\subsection{Validation by gel electrophoresis}

To validate the occurrence of the RCA reaction and feasibility of the proposed strategy, we performed an agarose gel electrophoresis experiment with bromophenol blue as the fluorescent indicator. As shown in Fig. S1, $\uparrow$ DNA bands in lane 1 and 6 correspond to $500 \mathrm{bp}$ and $5000 \mathrm{bp}$ DNA markers, respectively. DNA bands in lane 2 and 3 correspond to primer DNA S2 and circular template DNA S3, respectively. Long DNA band was observed in lane 4 when S2 was hybridized with S3 to form

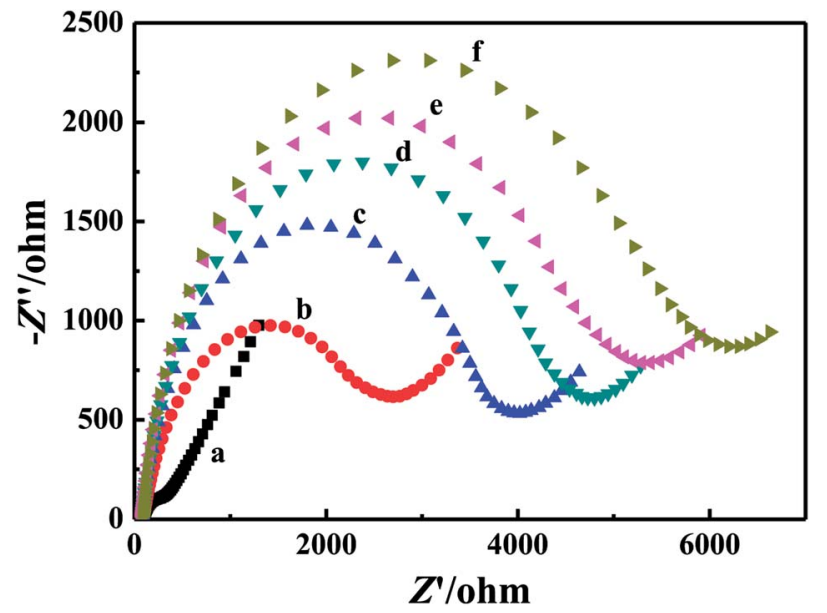

Fig. 2 Nyquist plots of EIS measurements for different modified electrodes in $5 \mathrm{mM}\left[\mathrm{Fe}(\mathrm{CN})_{6}\right]^{3-/ 4-}$ containing $0.1 \mathrm{M} \mathrm{KCl}$ and $0.1 \mathrm{M}$ $\mathrm{NaClO}_{4}$ : (a) bare Au electrode, (b) S1/Au, (c) P-S1/Au, (d) $\mathrm{TiO}_{2} / \mathrm{P}-\mathrm{S} 1 / \mathrm{Au}$, (e) $\mathrm{RCA} / \mathrm{TiO}_{2} / \mathrm{P}-\mathrm{S} 1 / \mathrm{Au}$, and (f) $\mathrm{S} 4 / \mathrm{RCA} / \mathrm{TiO}_{2} / \mathrm{P}-\mathrm{S} 1 / \mathrm{Au}\left(10 \mathrm{U} \mathrm{mL}{ }^{-1} \mathrm{~T} 4\right.$ PNK used as an example). circularization mixture. For a comparison, a new long DNA band appeared in lane 5, indicating the occurrence of the RCA reaction. The results of gel electrophoresis strongly support the principle of the RCA-based amplification strategy.

\subsection{Characterization of biosensor fabrication}

In order to demonstrate the feasibility of the designed biosensor, the electrode modification was confirmed by electrochemical impedance spectroscopy (EIS). The semicircle portion in an EIS corresponds to the electron-transfer limited process, and the increase of the semicircle diameter indicates the increase of the interfacial electron-transfer resistance $\left(R_{\mathrm{et}}\right){ }^{25}$ As shown in Fig. 2, compared with bare Au electrode (curve a), the electrode modified with S1 (curves b) shows a larger semicircular domain, implying a high electron transfer resistance. After the phosphorylation of S1 (curves c), much larger $R_{\text {et }}$ value was observed. $R_{\text {et }}$ was further increased after $\mathrm{TiO}_{2}$ NTs bonding on the surface of modified electrode (curve d) due to its poor conductivity. The addition of S3 and phi29 DNA polymerase led to an increase of the semicircular domain (curve e), which could
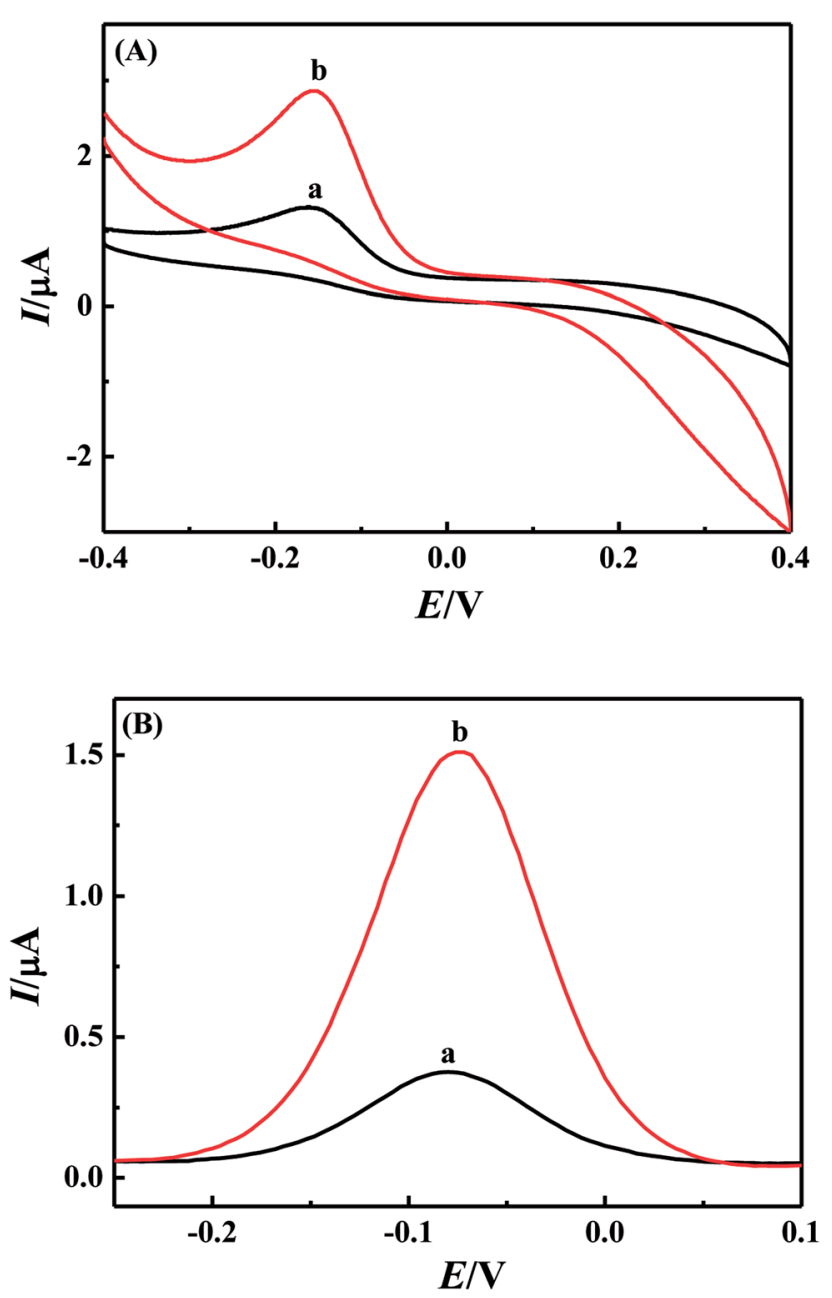

Fig. 3 (A) CV and (B) DPV curves in absence (a) and presence (b) of 20 $\mathrm{U} \mathrm{mL}^{-1} \mathrm{~T} 4 \mathrm{PNK}$ in $10 \mathrm{mM}$ Tris- $\mathrm{HCl}$ (pH 7.4, containing $0.1 \mathrm{M} \mathrm{NaCl}$, $1 \mathrm{mM} \mathrm{H}_{2} \mathrm{O}_{2}$ and $1 \mathrm{mM} \mathrm{HQ}$ ). 

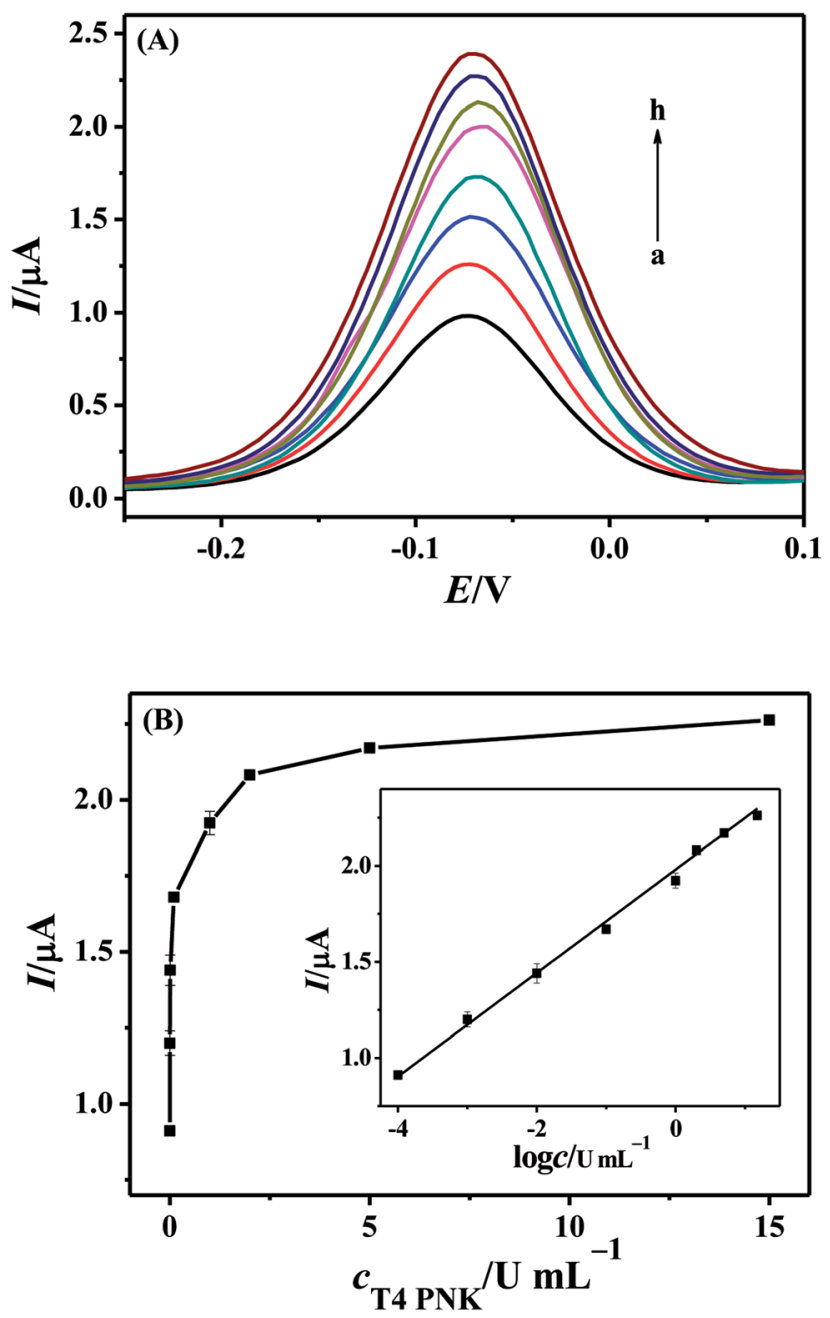

Fig. 4 (A) DPV curves of the HRP-SA/S4/RCA/TiO $2 / \mathrm{P}-\mathrm{S} 1 /$ Au electrode for the detection of T4 PNK with different concentrations: (a) 0.0001 (b) 0.001 , (c) 0.01 , (d) 0.1, (e) 1.0, (f) 2.0, (g) 5.0, and (h) $15.0 \mathrm{U} \mathrm{mL}^{-1}$ in $10 \mathrm{mM}$ Tris- $\mathrm{HCl}\left(\mathrm{pH} 7.4\right.$, containing $0.1 \mathrm{M} \mathrm{NaCl}, 1 \mathrm{mM} \mathrm{H}_{2} \mathrm{O}_{2}$ and $1 \mathrm{mM}$ $\mathrm{HQ}$ ) and (B) the relationship between the peak current and the concentration of T4 PNK. Inset in (B) shows the corresponding calibration curve of peak current vs. the logarithm of T4 PNK concentration.

be ascribed to the RCA reactions on electrode surface. Further increase of semicircular domain (curve f) demonstrated the successful hybridization of $\mathrm{S} 4$ with RCA reaction product. These
EIS results indicated the modification process of the electrode was achieved successfully.

In order to verify the feasibility of the developed method, we examined the electrochemical response in the absence and presence of T4 PNK. Fig. 3 displays $\mathrm{CV}$ and DPV response curves in absence and presence of $20 \mathrm{U} \mathrm{mL}^{-1} \mathrm{~T} 4 \mathrm{PNK}$ in $10 \mathrm{mM}$ Tris- $\mathrm{HCl}\left(\mathrm{pH}\right.$ 7.4, containing $0.1 \mathrm{M} \mathrm{NaCl}, 1 \mathrm{mM} \mathrm{H}_{2} \mathrm{O}_{2}$ and $1 \mathrm{mM} \mathrm{HQ}$ ). We observed that both CV and DPV exhibit a significant electrochemical response peak in the presence of target, indicating that the phosphorylation of T4 PNK functioned and promoted the specific combination of phosphate groups and $\mathrm{TiO}_{2}$ NTs, and resulting in RCA signal amplification reaction.

\subsection{Optimization of experimental parameters}

In order to achieve the best assay performance of developed biosensor, several crucial parameters were optimized as shown in Fig. S2. $\dagger$ Fig. S2A $\dagger$ presented the effect of phosphorylation time on the electrochemical response of the biosensor. With increasing phosphorylation time from 1 to $2 \mathrm{~h}$, reduction peak current increased gradually, indicating incremental degree of phosphorylation reaction. Response current reached the maximum value at phosphorylation time of $2 \mathrm{~h}$ due to a saturated phosphorylation of complementary DNA. Thus, $2 \mathrm{~h}$ was chosen as the optimal phosphorylation time in the following experiments. In this phosphorylation reaction, phosphate group is supplied by ATP. Therefore, concentration of ATP will influence phosphorylation level and detection sensitivity. As shown in Fig. S2B, $\uparrow$ reduction peak current increased with improving ATP concentration from 1 to $3 \mathrm{mM}$. Therefore, $3 \mathrm{mM}$ ATP was employed in this study. $\mathrm{TiO}_{2} \mathrm{NTs}_{\text {has }}$ been designed as a connection between phosphorylated DNA (P-S1/DNA) and RCA product. The concentration of $\mathrm{TiO}_{2}$ was investigated as show in Fig. S2C. $\dagger$ The maximum of response peak current was observed at $0.6 \mathrm{mM} \mathrm{TiO}_{2}$ NTs. Therefore, $0.6 \mathrm{mM}$ was employed as the optimal $\mathrm{TiO}_{2}$ concentration to obtain a high sensitivity.

To achieve optimal sensing performance, RCA experimental parameters were also optimized. The concentration of circularization mixture, RCA incubating time, and concentration of phi29 DNA polymerase were optimized as shown in Fig. S2D-F. $\dagger$ RCA was carried out at the condition of $60 \mathrm{nM}$ circularization mixture, $60 \mathrm{~min}$ RCA time, and $20 \mathrm{U} \mathrm{mL}^{-1}$ phi29 DNA

Table 2 Comparison of the detection performances of PNK activity with other methods

\begin{tabular}{|c|c|c|c|c|}
\hline Strategy & Technique & Linear range/ $\mathrm{U} \mathrm{mL}^{-1}$ & $\mathrm{DOL} / \mathrm{U} \mathrm{mL} \mathrm{L}^{-1}$ & Reference \\
\hline G-quadruplex/hemin DNAzyme & Colorimetry & $0.01-0.8$ & 0.01 & 19 \\
\hline DNA/PDANS & Fluorescence & $0.01-2.5$ & 0.01 & 15 \\
\hline Padlock $+\mathrm{LT}+\mathrm{T} 4 \mathrm{PNK}+\mathrm{T} 4$ ligase & Fluorescence & $0.001-0.1$ & 0.00038 & 14 \\
\hline RCA-chemiluminescence & CL & $0.01-3$ & 0.00022 & 47 \\
\hline $\mathrm{HP} 1 / \mathrm{AuNP} / \mathrm{g}-\mathrm{C}_{3} \mathrm{~N}_{4} / \mathrm{GCE}$ & PEC & $0.002-0.1$ & 0.001 & 23 \\
\hline $\mathrm{TiO}_{2}$ NTA electrode & $\mathrm{CV}$ & $0-30$ & 0.15 & 25 \\
\hline ALP/SA/phos-tag-biotin/P-dsDNA/AuNPs/GCE & DPV & $0.01-5$ & 0.0027 & 26 \\
\hline AuNP-S2/MCH/S1/Au & DPV & $0.001-10$ & 0.000776 & 27 \\
\hline $\mathrm{HRP}-\mathrm{SA} / \mathrm{S} 4 / \mathrm{RCA} / \mathrm{TiO}_{2} / \mathrm{P}-\mathrm{S} 1 / \mathrm{Au}$ & DPV & $0.0001-15$ & 0.00003 & This method \\
\hline
\end{tabular}


polymerase, respectively, in the following experiments. In addition, the effects of concentration of S4 DNA, HRP-SA, $\mathrm{H}_{2} \mathrm{O}_{2}$, and $\mathrm{HQ}$ on the electrochemical response of the biosensor were also studied. As shown in Fig. S3, $\uparrow 10 \mu \mathrm{M} \mathrm{S} 4,10 \mu \mathrm{g} \mathrm{mL}{ }^{-1} \mathrm{HRP}-$ $\mathrm{SA}, 1 \mathrm{mM} \mathrm{H}_{2} \mathrm{O}_{2}$, and $1 \mathrm{mM} \mathrm{HQ}$ were chosen as the optimal conditions for electrochemical monitoring T4 PNK activity in all subsequent experiments.

Fig. 3 shows CV and DPV response curves of biosensor for 20 $\mathrm{U} \mathrm{mL}^{-1} \mathrm{~T} 4 \mathrm{PNK}$ in $10 \mathrm{mM}$ Tris-HCl (pH 7.4), which exhibits significant electrochemical response signal in the presence of T4 PNK, indicating that electrochemical biosensor was successfully fabricated and could be applied to monitoring the activity of T4 PNK.

\subsection{Detection of T4 PNK activity}

Under the optimal experimental conditions, the as-proposed electrochemical biosensor was applied to investigate the activity of T4 PNK with different concentration. As shown in Fig. 4A, DPV peak current increased with the increasing of T4 PNK concentration. With increasing concentration of T4 PNK, more S1 DNA was phosphorylated and more $\mathrm{TiO}_{2}$ NTs were attached on the surface of electrode, resulting in immobilization of more amount of HRP-tagged RCA bioconjugate and enhanced current signal. Fig. 4B shows the relationship between the DPV peak current and the concentration of T4 PNK. Inset in Fig. 4B displays the corresponding calibration curve of peak current $v s$. the logarithm of $\mathrm{T} 4 \mathrm{PNK}$ concentration in the range of 0.0001 to $15 \mathrm{U} \mathrm{mL}^{-1}$. The linear regression equation is $I_{\mathrm{pc}}(\mu \mathrm{A})=0.262 \log c\left(\mathrm{U} \mathrm{mL}^{-1}\right)+$ 1.965 with a correlation coefficient of 0.9971 , where $I$ and $c$ are the DPV peak current intensity and T4 PNK concentration, respectively. The detection limit (LOD) of T4 PNK is calculated to be $0.00003 \mathrm{U} \mathrm{mL}^{-1}$ (signal-to-noise ratio of 3), which is better than that of previously reported methods as shown in Table 2. The high sensitivity of the proposed method can be ascribed to both the signal amplification effect of HRP-tagged RCA

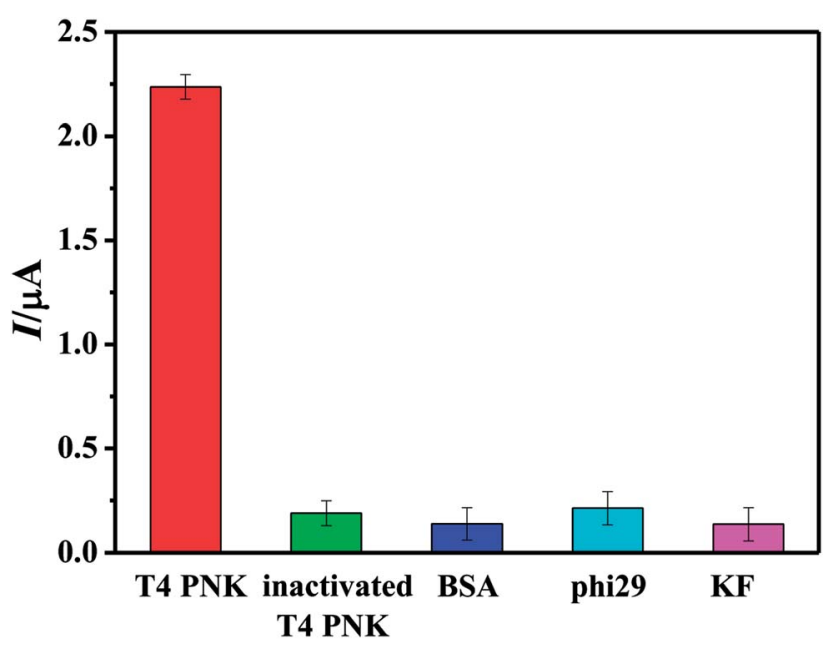

Fig. 5 Selectivity of the proposed amplification strategy for the T4 PNK assay. Experimental conditions: $15 \mathrm{U} \mathrm{mL}^{-1} \mathrm{~T} 4 \mathrm{PNK}, 20 \mathrm{U} \mathrm{mL}^{-1}$ inactivated T4 PNK, phi29 and KF, $1 \mathrm{mg} \mathrm{mL}^{-1} \mathrm{BSA}$. The error bars represent the standard deviation of three repetitive measurements.

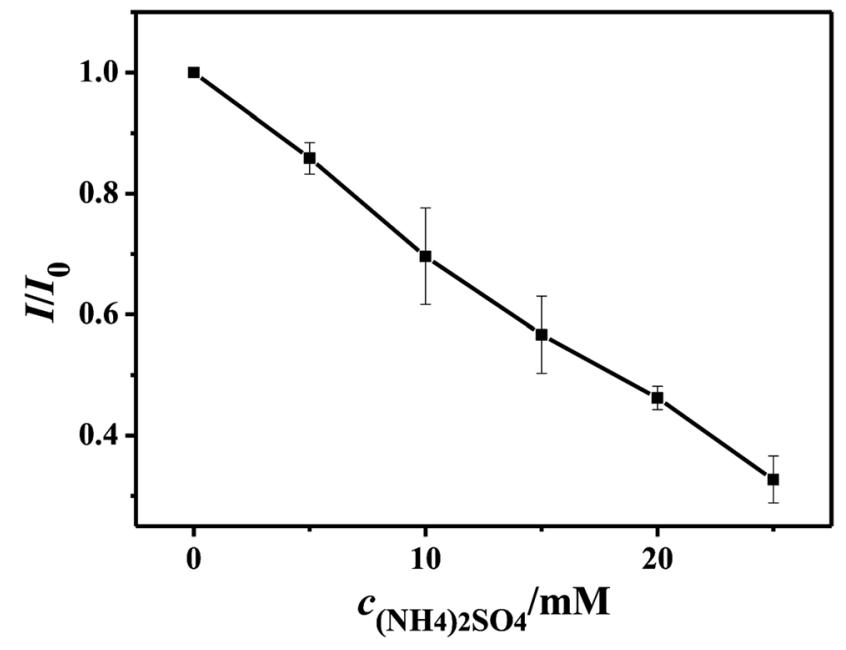

Fig. 6 Inhibition effect of $\left(\mathrm{NH}_{4}\right)_{2} \mathrm{SO}_{4}$ on T4 PNK activity. The assay was carried out in $10 \mathrm{mM}$ Tris- $\mathrm{HCl}\left(\mathrm{pH} 7.4,0.1 \mathrm{M} \mathrm{NaCl}, 1 \mathrm{mM} \mathrm{H}_{2} \mathrm{O}_{2}\right.$ and $1 \mathrm{mM} \mathrm{HQ}$ ) containing $10 \mathrm{U} \mathrm{mL}^{-1} \mathrm{~T} 4 \mathrm{PNK}$.

bioconjugate and the efficient attachment of $\mathrm{TiO}_{2}$ NTs to phosphorylated DNA by T4 PNK. The relative standard deviation (RSD) for 4 successive determinations was $4.68 \%$, suggesting a good stability and reproducibility.

\subsection{Specificity and inhibition investigation}

To further verify the specificity of T4 PNK detection, the influence of other protein and polymerase on the T4 PNK assay has been investigated. Four interferents, including inactivated T4 PNK, BSA, phi29 DNA polymerase (phi29) and Klenow fragment DNA polymerase (KF), were chosen to evaluate the specificity of the T4 PNK assay. It is clearly illustrated in Fig. 5 that only T4 PNK caused a significant signal in DPV response, whereas inactivated T4 PNK and other interferents failed to cause obvious current response even though their concentration is much higher than that of T4 PNK. Therefore, this is a highly specific and reliable method for studying T4 PNK activity.

In order to assess the applicability of the proposed strategy in screening of T4 PNK inhibitor, $\left(\mathrm{NH}_{4}\right)_{2} \mathrm{SO}_{4}$ was selected as a model to investigate the inhibition effect. The inhibition percentage (IP) was calculated according to the equation: IP $(\%)=I / I_{0} \times 100 \%$, where $I$ and $I_{0}$ are DPV peak currents in the presence and absence of inhibitor, respectively. As shown in Fig. 6, the DPV peak current decreased with the increasing concentration of $\left(\mathrm{NH}_{4}\right)_{2} \mathrm{SO}_{4}$. And the halfmaximal inhibition concentration $\left(\mathrm{IC}_{50}\right)$ of $\left(\mathrm{NH}_{4}\right)_{2} \mathrm{SO}_{4}$ was calculated to be $18 \mathrm{mM}$, which is consistent with previous reports of electrochemical methods. These results showed that the method could be used for screening of T4 PNK inhibitors.

\section{Conclusions}

In summary, we have developed a novel sensitive method for detection of T4 PNK activity and inhibition based on dual- 
signaling amplification and RCA technique. Taking advantage of the specific coupling of the $\mathrm{TiO}_{2}$ NTs and phosphate groups and accumulation of RCA products on electrode surface, the electrochemical signal can be greatly amplified after an elaborated design so as to improve the detection sensitivity. Additionally, the inhibition effects of $\left(\mathrm{NH}_{4}\right)_{2} \mathrm{SO}_{4}$ and selectivity have been evaluated based on this strategy, showing a powerful tool for biomedical research and clinical diagnosis.

\section{Conflicts of interest}

There are no conflicts to declare.

\section{Acknowledgements}

The authors gratefully acknowledge the financial support from the National Natural Science Foundation of China (21665027, 21565031, and 21463028), YMU-DEAKIN International Associated Laboratory on Functional Materials, and Mentor and Sailing Plan of School of Chemistry and Environment, Yunnan Minzu University, PR China.

\section{References}

1 C. C. Richardson, Proc. Natl. Acad. Sci. U. S. A., 1965, 54, 158165.

2 A. Novogrodsky and J. Hurwitz, J. Biol. Chem., 1966, 241, 2923-2932.

3 A. Novogrodsky, M. Tal, A. Traub and J. Hurwitz, J. Biol. Chem., 1966, 241, 2933-2943.

4 S. Sharma, K. M. Doherty and R. M. Brosh, Biochem. J., 2006, 398, 319-337.

5 D. H. Phillips and V. M. Arlt, Nat. Protoc., 2007, 2, 2772-2781.

6 A. Rasouli-Nia, F. Karimi-Busheri and M. Weinfeld, Proc. Natl. Acad. Sci. U. S. A., 2004, 101, 6905-6910.

7 F. Karimi-Busheri, A. Rasouli-Nia, J. Allalunis-Turner and M. Weinfeld, Cancer Res., 2007, 67, 6619-6625.

8 C. C. Richardson, Proc. Natl. Acad. Sci. U. S. A., 1965, 54, 158165.

9 F. Karimi-Busheri, G. Daly, P. Robins, B. Canas, D. J. C. Pappin, J. Sgouros, G. G. Miller, H. Fakhrai, E. M. Davis, M. M. Le Beau and M. Weinfeld, J. Biol. Chem., 1999, 274, 24187-24194.

10 M. Meijer, F. Karimi-Busher, T. Y. Huang, M. Weinfeld and D. Young, J. Biol. Chem., 2002, 277, 4050-4055.

11 L. K. Wang and S. Shuman, J. Biol. Chem., 2001, 276, 2686826874.

12 C. Chappell, L. A. Hanakahi, F. Karimi-Busheri, M. Weinfeld and S. C. West, EMBO J., 2002, 21, 2827-2832.

13 N. K. Bernstein, R. S. Williams, M. L. Rakovszky, D. Cui, R. Green, F. Karimi-Busheri, R. S. Mani, S. Galicia, C. A. Koch, C. E. Cass, D. Durocher, M. Weinfeld and J. N. M. Glover, Mol. Cell, 2005, 17, 657-670.

14 H. X. Jiang, Y. P. Xu, L. H. Dai, X. W. Liu and D. M. Kong, Sens. Actuators, B, 2018, 260, 70-77.

15 Y. Cen, W. J. Deng, R. Q. Yu and X. Chu, Talanta, 2018, 180, 271-276.
16 C. B. Ma, S. X. Jin, J. Wang, K. M. Wang, H. S. Liu and K. F. Wu, Anal. Methods, 2016, 8, 1989-1994.

17 T. Hou, X. Z. Wang, X. J. Liu, T. T. Lu, S. F. Liu and F. Li, Anal. Chem., 2014, 86, 884-890.

18 L. J. Wang, Q. Y. Zhang, B. Tang and C. Y. Zhang, Anal. Chem., 2017, 89, 7255-7261.

19 H. S. Liu, C. B. Ma, J. Wang, H. C. Chen and K. M. Wang, Anal. Biochem., 2017, 517, 18-21.

20 C. Jiang, C. Y. Yan, J. H. Jiang and R. Q. Yu, Anal. Chim. Acta, 2013, 766, 88-93.

21 L. Lin, D. M. Shi, Q. F. Li, G. F. Wang and X. J. Zhang, Anal. Methods, 2016, 8, 4119-4126.

22 J. Du, Q. F. Xu, X. Q. Lu and C. Y. Zhang, Anal. Chem., 2014, 86, 8481-8488.

23 J. Y. Zhuang, W. Q. Lai, M. D. Xu, Q. Zhou and D. P. Tang, ACS Appl. Mater. Interfaces, 2015, 7, 8330-8338.

24 Z. H. Wang, Z. Y. Yan, F. Wang, J. B. Cai, L. Guo, J. K. Su and Y. Liu, Biosens. Bioelectron., 2017, 97, 107-114.

25 B. J. Wang, Y. F. Xiong, L. Lin, X. J. Zhang and G. F. Wang, Anal. Methods, 2015, 7, 10345-10349.

26 Q. M. Zhang, X. Li, B. C. Li, H. S. Yin and S. Y. Ai, Anal. Methods, 2015, 7, 9984-9991.

27 L. Cui, Y. Y. Li, M. F. Lu, B. Tang and C. Y. Zhang, Biosens. Bioelectron., 2018, 99, 1-7.

28 Q. M. Zhang, Z. Li, Y. L. Zhou, X. Li, B. C. Li, H. S. Yin and S. Y. Ai, Sens. Actuators, B, 2016, 225, 151-157.

29 L. Lin, Y. Liu, J. Yan, X. S. Wang and J. H. Li, Anal. Chem., 2013, 85, 334-340.

30 Y. L. Peng, J. H. Jiang and R. Q. Yu, RSC Adv., 2013, 3, 1812818133.

31 T. Hou, X. Z. Wang, X. L. Liu, C. Pan and F. Li, Sens. Actuators, B, 2014, 202, 588-593.

32 Y. H. Wang, X. X. He, K. M. Wang, X. Q. Ni, J. Su and Z. F. Chen, Biosens. Bioelectron., 2012, 32, 213-218.

33 G. F. Wang, X. P. He, G. Xu, L. Chen, Y. H. Zhu, X. J. Zhang and L. Wang, Biosens. Bioelectron., 2013, 43, 125-130.

34 G. F. Wang, L. Chen, X. P. He, Y. H. Zhu and X. J. Zhang, Analyst, 2014, 139, 3895-3900.

35 C. Feng, X. X. Mao, Y. C. Yang, X. L. Zhu, Y. M. Yin and G. X. Li, J. Electroanal. Chem., 2016, 781, 223-232.

36 X. J. Liu, M. M. Song, T. Hou and F. Li, ACS Sens., 2017, 2, 562-568.

37 Z. Y. He, J. Wei, C. F. Gan, W. P. Liu and Y. J. Liu, RSC Adv., 2017, 7, 39906-39913.

38 L. Zhou, L. J. Ou, X. Chu, G. L. Shen and R. Q. Yu, Anal. Chem., 2007, 79, 7492-7500.

39 A. Fire and S. Q. Xu, Proc. Natl. Acad. Sci. U. S. A., 1995, 92, 4641-4645.

40 B. Schweitzer, S. Roberts, B. Grimwade, W. Shao, M. Wang, Q. Fu, Q. Shu, I. Laroche, Z. Zhou, V. T. Tchernev, J. Christiansen, M. Velleca and S. F. Kingsmore, Nat. Biotechnol., 2002, 20, 359-365.

41 L. T. Yang, C. W. Fung, E. J. Cho and A. D. Ellington, Anal. Chem., 2007, 79, 3320-3329.

42 H. L. Li, J. G. Xu, Z. M. Wang, Z. S. Wu and L. Jia, Biosens. Bioelectron., 2016, 86, 1067-1073. 
43 C. Feng, X. X. Mao, Y. C. Yang, X. L. Zhu, Y. M. Yin and G. X. Li, J. Electroanal. Chem., 2016, 781, 223-232.

44 T. T. Fan, Y. Du, Y. Yao, J. Wu, S. Meng, J. J. Luo, X. Zhang, D. Z. Yang, C. Y. Wang, Y. Qian and F. L. Gao, Sens. Actuators, $B, 2018,266,9-18$.
45 K. W. Park, C. Y. Lee, B. S. Batule, K. S. Park and H. G. Park, RSC Adv., 2018, 8, 1958-1962.

46 Y. Li, W. Q. Dai, X. F. Lv and Y. L. Deng, Anal. Methods, 2018, 10, 1767-1773.

47 W. Tang, G. C. Zhu and C. Y. Zhang, Chem. Commun., 2014, 50, 4733-4735. 